\title{
The ecosystem service value as a new eco-efficiency indicator for industrial parks
}

\author{
Yao Shi ${ }^{\text {a }}$, Jingru Liu ${ }^{\text {b, }{ }^{*}, \text { Han Shi }}{ }^{c}$, Huiquan $\mathrm{Li}^{\text {a, }}{ }^{\mathrm{d}}$, Qiang $\mathrm{Li}^{\mathrm{a}}$ \\ ${ }^{a}$ Key Laboratory of Green Process and Engineering, National Engineering Laboratory for Hydrometallurgical Cleaner Production Technology, Institute of \\ Process Engineering, CAS, Beijing 100190, China \\ b State Key Laboratory of Urban and Regional Ecology, Research Center for Eco-Environmental Sciences, CAS, Beijing 100085, China \\ ${ }^{\mathrm{c}}$ Department of Public Policy, City University of Hong Kong, 999077, Hong Kong, China \\ d School of Chemistry and Chemical Engineering, University of Chinese Academy of Sciences, Beijing 100049, China
}

\section{A R T I C L E I N F O}

\section{Article history:}

Received 26 October 2016

Received in revised form

20 June 2017

Accepted 21 June 2017

Available online 21 June 2017

Handling Editor: Yutao Wang

\section{Keywords:}

Industrial park

Eco-efficiency

Ecosystem services

Land use

\begin{abstract}
A B S T R A C T
The ecologicalization of industrial parks and the construction of eco-industrial parks (EIPs) are new trends within industrial clusters. However, land use changes and the related losses of ecosystem services are often neglected in ecological evaluations of industrial parks. This negligence is particularly significant in developing countries such as China, where the economic outputs of land use have significantly improved, but a considerable number of farms and forests have been exposed to industrial land, which greatly reduces the regional natural capital. This article proposes a set of eco-efficiency indicators for evaluating the ecological performance of an industrial park from the perspective of the ecosystem services or natural capital reflected by such services. A corresponding efficiency evaluation model and index system was constructed and used in a case study of Ningguo Gangkou industrial park in eastern China. Based on a comparative analysis of the eco-efficiency of the Gangkou industrial park in 2007 and 2015, we found that although the total ecosystem service value (ESV) of Gangkou in 2015 had increased by $27 \%$ compared with that of 2007, the maintenance of the ecological regulating and supporting services of the park had declined, and the indirect economic value of these services had decreased by $14 \%$. Because of the development of the park over the last 10 years, the different ecosystems and the relevant ecosystem services had undergone different degrees of changes. The main task of this study was to establish an ESVbased eco-efficiency evaluation index system that can be used by decision makers for sustainable landscape planning and development.
\end{abstract}

๑) 2017 Elsevier Ltd. All rights reserved.

\section{Introduction}

In China, the development of eco-industrial parks (EIPs) reflects the government's attempt to implement the circular economy that focuses on resource shortages and environmental pollution issues related to regional economic development (Shi et al., 2003a, 2010, b; Shi et al., 2012a, b). Over the past two decades of methodological and practical development of EIPs, most of the focus have been on the exchanges of by-products and waste, their influence on the environment, and the metabolism of natural resources and energy

\footnotetext{
* Corresponding author. State Key Laboratory of Urban and Regional Ecology, Research Center for Eco-Environmental Sciences, Chinese Academy of Sciences, 18 Shuangqing Road, Haidian 100085, China.

E-mail address: liujingru@rcees.ac.cn (J. Liu).
}

(Côté, 1998; Lowe, 1997). With the rapid development and extension of EIPs in recent years (Bai et al., 2014; Panyathanakun et al., 2013; Shi et al., 2010, 2011; Yu et al., 2014a; Yu et al., 2014b; Zhang et al., 2010), scholars have begun studying the ecological issues pertaining to EIPs (D'Anna and Cascini, 2016; Lowitt and Côté, 2013; Sokka et al., 2011), and the primary goal of these ecological discussions is to assess the associated ecosystem services (Bakshi and Small, 2011; Michelsen et al., 2012; Yu et al., 2015).

The eco-efficiency of the industrial park is determined by two aspects, the efficiency of ecosystem services preservation and the intensity of pollutant emission. In addition to the efficiency of resource and energy use, we should also pay attention to the land use pattern and the maintenance efficiency of its ecosystem service. The sustainability of EIPs requires a re-examination of the effects of man-made capital (including construction, machinery and 
equipment, and infrastructure), human capital and natural capital in the whole development process (Costanza et al., 2014). The higher the efficiency of land resource conservation and natural ecosystem services preservation is, the higher the level of sustainable development of the EIPs will be.

As the carrier of human social and economic activities, the land is also the foundation of natural ecosystem services, which ensure the ecological health of developing cities and regions. As a type of natural resource, the land provides natural ecosystem services, such as biomass production, recreational or activity space provisions, water retention, environmental cleaning, carbon sequestration or climate regulation, and biodiversity conservation (Costanza et al., 1997; Ouyang et al., 2016). Urbanization and industrialization have changed the land use pattern dramatically, which endangers food security and threatens the irreplaceable ecosystem services utilized by urban populations (Shi et al., 2012c). The development, utilization and management of land resources in industrial parks will directly affect the ecological security of urban and regional ecological health (Bakshi and Small, 2011; Lowitt and Côté, 2013; Shi et al., 2011).

Compared with the current EIP eco-efficiency evaluation models, which are mostly based on resources and energy metabolism and environmental impact analyses (Felicio et al., 2016; Park and Behera, 2014; Shi et al., 2011; Tian et al., 2014), this research aimed to explore a new eco-efficiency evaluation method based on ecosystem services value (ESV) accounting. First, new indicators based on ESV accounting were established. Using Gangkou industrial park as an example, a dynamic analysis was then performed for the changes in ESV from 2007 (the history year) to 2015 (the status year), and the maintenance of natural capital and eco-efficiency levels were evaluated and explored. Future land-use and industrial development policy suggestions for Gangkou are provided from the perspective of ecological management, and the uncertainties of this study and future research are discussed.

\section{Methodology and data collection}

\subsection{Research area}

Gangkou industrial park is $95 \mathrm{~km}^{2}$ in total area and located in the southeast of Anhui Province in the middle eastern area of China. The southwest portion of the park is at a higher elevation than the northeast portion and presents slopes of $10-30^{\circ}$ around the hilly topography. The park has many rivers that stream from west to the east into the Shuiyangjiang River, which is one of the branches of the Yangtze River. In 2007, Gangkou was a county with a high density of farmland and forest and well-developed water systems. The land use patterns changed dramatically since Gangkou was planned as an industrial park. In 2007, approximately $40 \%$ of the Gangkou industrial park was covered with forest, approximately $10 \%$ was covered with grassland, and approximately $30 \%$ was covered by farmland, whereas in 2015 , the area covered by forest increased to $50 \%$, the area covered by farmland slightly decreased, and the area covered by urban land slightly increased (see Fig. 1). Gangkou is a typical new-planned model of EIP with a harmonious coexistence of natural ecology through an optimized pattern of land use.

\subsection{Research framework and data collection}

The following analysis framework was applied in this study (Fig. 2):

1) A set of eco-efficiency evaluation indicators based on ESV accounting was established;

2) A comparison of the ESV-based eco-efficiencies in 2007 and 2015 in Gangkou park was performed through the proposed indicator system;

3) A land use ecological suitability analysis of Gangkou park was conducted using a GIS platform;

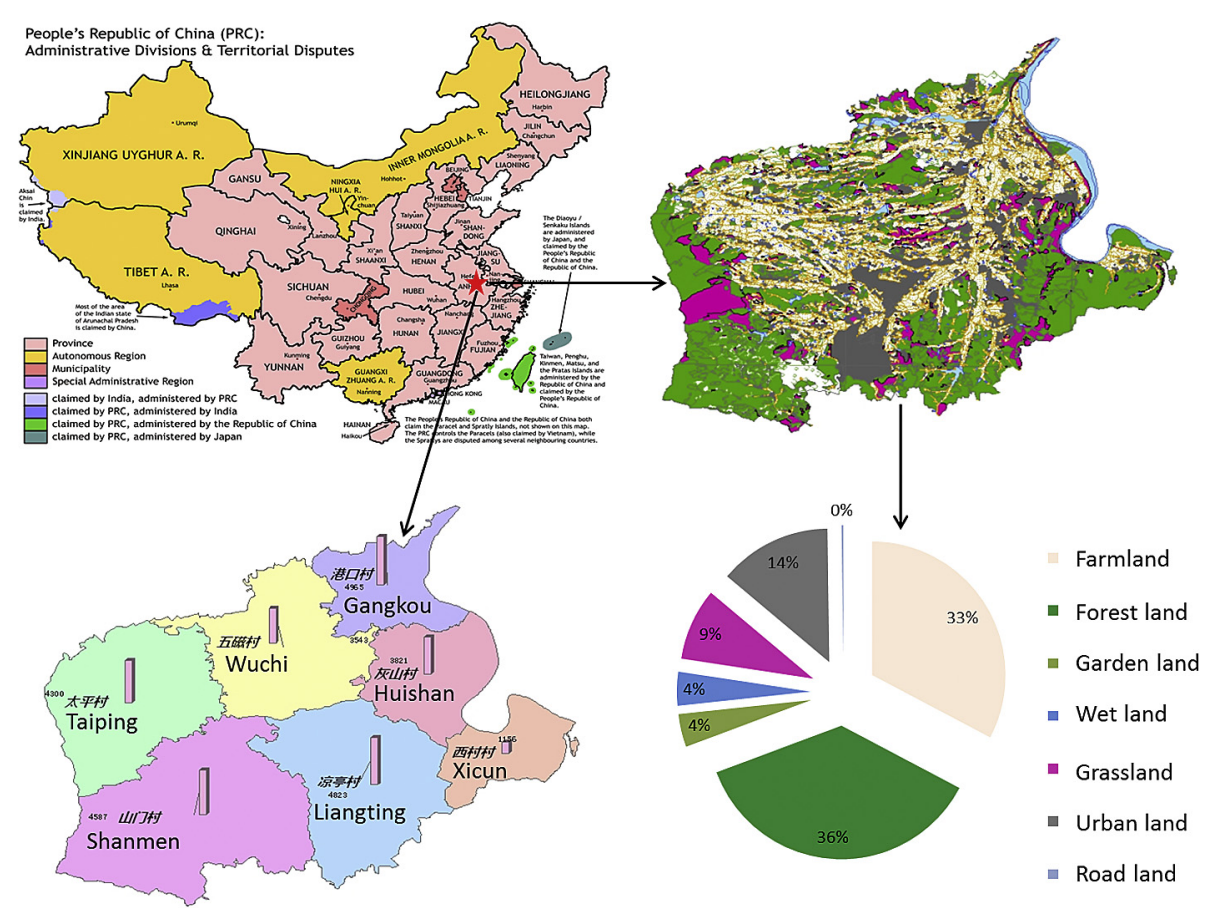

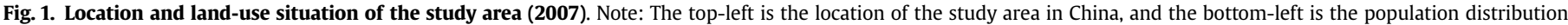

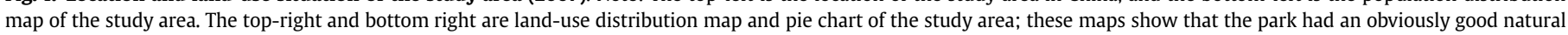
ecological foundation in 2007, which had a high density of farmland and forest and well-developed water systems. 


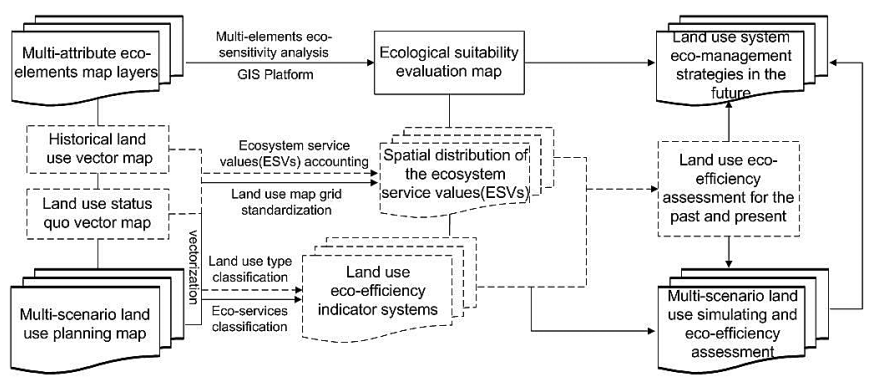

Fig. 2. Land system management framework of EIPs based on ecosystem service. Note: The dashed elements are evaluated in this study. The others, including the multielement eco-sensitivity analysis and land-use system eco-management strategies, are follow-up studies of this framework.

4) Different land use scenarios were set according to the future planning of the park and corresponding eco-efficiencies were analyzed;

5) Mitigation measures or compensation for significant negative impacts were recommended via a comparison of the scenario analyses.

This research included the collection and collation of the following data from 2007 to 2015: 1) land use patterns in 2007 and $2015 ; 2$ ) economic output per unit of different land use types (except for urban construction land); 3) regulating and supporting service values per unit provided by different ecosystems; 4) TM remote sensing images, spatial distributions and normalized difference vegetation index (NDVI) of the park's land use types according to supervision classification and the spectrum inversion method; and 5) consumer price index (CPI) data, which were used to unify the different time periods of the ESV for specific years of constant price.

\subsection{Measurement of industrial park land ecosystem services}

The ESV proposed by Costanza (Costanza et al., 1997, 2014), the research results of ESV by scholars in China, and the phased achievements of the Chinese "Biodiversity and Ecosystem Service Economics (TEEB)" research in 2015 (Lan et al., 2015; TEEB, 2010, 2013) were used to present the different types of terrestrial ecosystems in China (Table 1) and the empirical parameters of the various ESVs. Because of the lack of available parameters for the ESVs of non-natural land ecosystem types or the urban built-up areas, these ecosystem types were not considered, and certain parameters that returned negative values were also excluded.

Generally, the regulating and supporting service values of the cities or small-scale-region ecosystems should be calculated based on local parameters that are mostly derived from field experiments. To determine the material-supplying and culture and recreationproviding services and their direct economic values, a method for combining statistical data with social survey data is generally used (Daily et al., 2000; Ouyang et al., 1999). Because few local parameters were obtained for the park's ecosystem service values, we used a Chinese average value to account for the regulating and supporting services and their indirect economic values. Related sector parameters were used to account for the material-supplying and culture and recreation-providing services of the different land ecosystems and their direct economic values (Tables 1 and 2).

The ESV of the same land type changes in relation to spatial and temporal differences. In recent years, scholars have begun to develop different methods for modifying the value parameters of the ESV, including the elastic theory method (Kreuter et al., 2001; Liu et al., 2012), the Markova model (Luo and Zhang, 2014), and a local investigation combined with an expert consultation method. The spatial-temporal heterogeneity of the ESV in certain specific areas was evaluated using the NDVI index of TM remote sensing inversions, and the conversion rate was modified to determine the monetary value of the services per unit area of the four natural ecosystem types in the study area: farmland, garden land, forest and grassland. We then determined the modification coefficient $\lambda$,

Table 1

ESVs for different types of terrestrial ecosystems in Gangkou EIP.

\begin{tabular}{|c|c|c|c|c|c|c|c|c|c|c|c|}
\hline \multirow{2}{*}{$\begin{array}{l}\text { Ecosystem } \\
\text { type }\end{array}$} & \multicolumn{7}{|c|}{ Indirect Value $^{\mathrm{a}}$} & \multicolumn{3}{|c|}{ Direct Value $^{\mathrm{b}}$} & \multirow{2}{*}{$\begin{array}{l}\text { Total value } \\
\text { per area }\end{array}$} \\
\hline & $\begin{array}{l}\text { Climate } \\
\text { regulation }\end{array}$ & $\begin{array}{l}\text { Atmosphere } \\
\text { regulation }\end{array}$ & $\begin{array}{l}\text { Humidity } \\
\text { regulation }\end{array}$ & $\begin{array}{l}\text { Water and soil } \\
\text { conservation }\end{array}$ & $\begin{array}{l}\text { Soil } \\
\text { formation }\end{array}$ & $\begin{array}{l}\text { Waste } \\
\text { recycling }\end{array}$ & $\begin{array}{l}\text { Biological } \\
\text { control }\end{array}$ & $\begin{array}{l}\text { Food } \\
\text { supply }\end{array}$ & $\begin{array}{l}\text { Raw } \\
\text { material }\end{array}$ & $\begin{array}{l}\text { Culture and } \\
\text { recreation }\end{array}$ & \\
\hline Farmland $^{1)}$ & 442.4 & 787.5 & 530.9 & $-{ }^{\mathrm{d}}$ & 1291.9 & 1451.2 & 628.2 & $\begin{array}{l}5514.5 \\
(10315.9)\end{array}$ & $\begin{array}{l}1378.6 \\
(2578.9)\end{array}$ & $97.2(192.8)$ & $\begin{array}{l}12122.4 \\
(18219.7)\end{array}$ \\
\hline $\begin{array}{l}\text { Garden } \\
\text { land }^{2)}\end{array}$ & 1265.5 & 1170.3 & 41.5 & 796.8 & 1291.9 & 722.1 & 16.6 & $\begin{array}{l}4989.4 \\
(11135.4)\end{array}$ & $\begin{array}{l}11642 \\
(25984)\end{array}$ & $102.1(943.3)$ & $\begin{array}{l}22038 \\
(43367)\end{array}$ \\
\hline $\begin{array}{l}\text { Forest } \\
\qquad \text { land }^{3)}\end{array}$ & 1902.5 & 1592.8 & 1769.7 & 796.8 & 2588.2 & 1159.2 & 1924.6 & $\begin{array}{l}117.5 \\
(154.7)\end{array}$ & $\begin{array}{l}2232.8 \\
(2938.9)\end{array}$ & $424.8(2513.1)$ & $\begin{array}{l}14509 \\
(17341)\end{array}$ \\
\hline Grassland $^{4)}$ & 707.9 & 796.4 & 707.9 & 102.9 & 1725.5 & 1159.2 & 964.5 & $27.4(30.1)$ & $36.2(39.8)$ & $149.2(208.9)$ & $\begin{array}{l}6377.1 \\
(6443.1)\end{array}$ \\
\hline Wet land ${ }^{5)}$ & - & 407.0 & 18033.2 & - & 8.8 & 16086.6 & 2203.3 & $\begin{array}{l}9757.2 \\
(19069.2)\end{array}$ & $\begin{array}{l}4181.6 \\
(8172.5)\end{array}$ & $199.2(250.8)$ & $\begin{array}{l}50877 \\
(64231)\end{array}$ \\
\hline $\begin{array}{l}\text { Urban } \\
\qquad \text { land }^{\mathrm{c},} \text { 6) }\end{array}$ & - & - & -6678 & 3480 & - & -2174.1 & - & - & - & - & -5372.1 \\
\hline Road land ${ }_{6}^{c,}$ & - & - & - & 3480 & - & - & - & - & - & - & 3480 \\
\hline $\begin{array}{l}\text { Other } \\
\text { land }^{6)}\end{array}$ & - & - & 26.5 & - & 17.7 & 8.8 & 300.8 & - & - & - & 353.8 \\
\hline Total Value & 4318.3 & 4754 & 14431.7 & 8656.5 & 6924 & 18413 & 6038 & $\begin{array}{l}20406 \\
(40705)\end{array}$ & $\begin{array}{l}19471 \\
(39714)\end{array}$ & 972.5 (4108.9) & $\begin{array}{l}104385 \\
(148063)\end{array}$ \\
\hline
\end{tabular}

a The indirect values of each ecosystem are based on literature reviews.

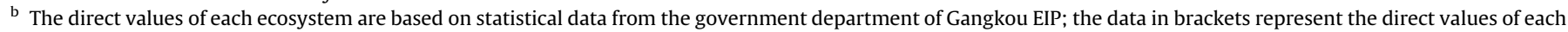
ecosystem in 2015. The concrete data sources are shown in Table 2.

c Urban and road land are treated as special terrestrial ecosystems; negative values were not assigned for certain parameters that have not been thoroughly studied.

d The horizontal line in the table indicates no data.

Unit: million RMB Yuan 
Table 2

Data sources of direct values for different types of ecosystems in Gangkou EIP.

\begin{tabular}{|c|c|c|c|}
\hline \multirow{2}{*}{$\begin{array}{l}\text { Ecosystem } \\
\text { Type }\end{array}$} & \multicolumn{3}{|c|}{ Data source of the direct value based on economic output } \\
\hline & Food supply & Raw material & Culture and recreation \\
\hline Farmland & $\begin{array}{l}\text { Cereals, } \\
\text { beans, } \\
\text { potatos }\end{array}$ & $\begin{array}{l}\text { Cotton, oil, } \\
\text { hemp }\end{array}$ & $\begin{array}{l}\text { The empirical data of different } \\
\text { ecosystems experiencing tourism } \\
\text { income, which was provided by the }\end{array}$ \\
\hline $\begin{array}{l}\text { Garden } \\
\text { land }\end{array}$ & $\begin{array}{l}\text { Fruits and } \\
\text { vegetables }\end{array}$ & $\begin{array}{l}\text { Tobacco and } \\
\text { tea }\end{array}$ & $\begin{array}{l}\text { local tourism management } \\
\text { department }\end{array}$ \\
\hline Forest land & $\begin{array}{l}\text { Nuts, } \\
\text { walnuts, } \\
\text { apricots }\end{array}$ & $\begin{array}{l}\text { Wood and } \\
\text { Camellia } \\
\text { oleifera seed }\end{array}$ & \\
\hline Grassland & $\begin{array}{l}\text { Meat, milk, } \\
\text { eggs, honey }\end{array}$ & Fur & \\
\hline Wet land & $\begin{array}{l}\text { Fish, shrimp, } \\
\text { crabs and } \\
\text { shellfish }\end{array}$ & $\begin{array}{l}\text { Tap-water } \\
\text { production } \\
\text { and supply }\end{array}$ & \\
\hline
\end{tabular}

Unit: million RMB Yuan

which can reflect the ecosystem spatial heterogeneity (Shi et al., 2012c), as follows:

$\lambda=\frac{\sum\left[N D V I_{i}-\min (N D V I)\right] /[\max (N D V I)-\min (N D V I)]}{n}$

where NDVIi is the NDVI index value of the ith mesh of the study area, min (NDVI) is the minimum value of the NDVI in all meshes, max (NDVI) is the maximum value of the NDVI in all meshes, and " $n$ " is the number of all meshes. The grid sizes of the TM image data are $30 \mathrm{~m}^{*} 30 \mathrm{~m}$ (Fig. 3 ).

This modification coefficient based on the NDVI index is mainly used to correct the value of the natural land system in the industrial park, including farmland, garden land, forest land and grassland. Water areas and artificial ecosystems were not included.

Therefore, the total value of the land ecosystem services in the study area at a specific period in time can be expressed as follows:

$E S V=\sum \sum \lambda_{i} \alpha_{i j} S_{i}$

where ESV indicates the total value of the land ecosystem services for the study area; $\alpha_{i j}$ is the service-to-monetary value conversion rate when the class $i$ land ecosystem provides a class $j$ service and represents the parameter for a terrestrial ecosystem service value per unit area; $\lambda_{i}$ is the class $i$ land ecosystem's modification coefficient for the NDVI value; and $S_{i}$ is the area of the class $i$ land ecosystem.

Moreover, the value of the ecosystem services was also unified with the fixed price of the specific research year using the economics concepts of comparable price and comparable growth rate (Shi et al., 2012c). Compared to the base year of 2007, the comparable growth rate of the ESV in current year of 2015 was as:

$C R_{2015}=E S V_{2015} /\left[E S V_{2007} \times\left(1+I R_{2015}\right)\right]-1$

where $C R_{2015}$ indicates the comparable growth rate of the ESV in $2015, I R_{2015}$ indicates the inflation rate in 2015, and

$I R_{2015}=\left(C P I_{2015}-C P I_{2007}\right) / C P I_{2007} \times 100 \%$

Then, the current year's comparable ESV is calculated as

$$
C E S V_{2015}=E S V_{2007} \times\left(C R_{2015}+1\right)=E S V_{2015} /\left(1+I R_{2015}\right)
$$
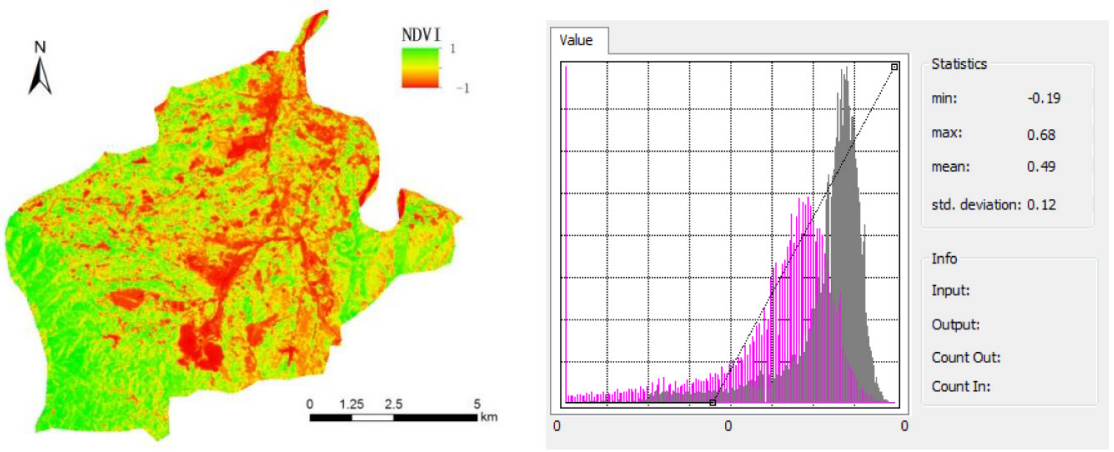

a

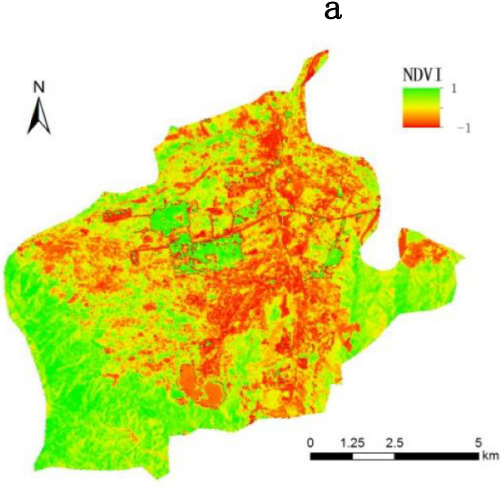

C b

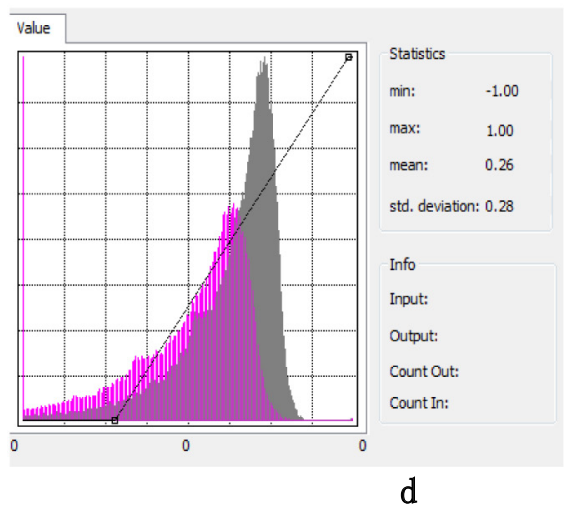

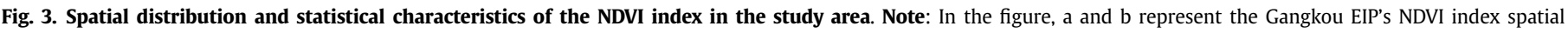
distribution and its statistical characteristics in 2007; c and d represent the NDVI index spatial distribution and its statistical characteristics in 2015. 


\subsection{Eco-efficiency index system of EIPS based on the ESV}

Two types of eco-efficiency indicators based on ecosystem service values are considered: economic indicators and environmental indicators. The economic indicators include the material supply, culture and recreation service values provided by each type of land use, which can be calculated through their direct economic output. The environmental indicators include regulating and supporting services, which can be calculated through their indirect economic output. If the difference between the direct economic value and indirect economic value is large, then the two values can be logarithmically standardized as follows to calculate the Eco-Ef:

$E c o-E f_{i}=P_{i} / E S V_{i}$ or $E c o-E f=\lg (P) / \lg (E S V)$

where $E c o-E f_{i}$ represents the eco-efficiency of the class $i$ land ecosystem; $P_{i}$ represents the representative economic output of the class $i$ land ecosystem, which is the direct economic value of the class $i$ land ecosystem services; and $E S V_{i}$ represents the indirect economic value of the class $i$ land ecosystem services.

In accordance with the different types of ecosystems and their services, we can establish two different eco-efficiency evaluation index systems for EIPs: one system for different land ecosystem types (see Eco-Ef 1 ) and one system for different ecosystem service types (Eco-Ef 2) (see Table 3).

This index can also explain the eco-development level of the Gangkou EIP from two perspectives: land use patterns and the ESV

Table 3

Eco-efficiency indicator systems based on the ecosystem services for EIPs.

\begin{tabular}{|c|c|c|c|}
\hline & Indicator & Definition & Explanation \\
\hline \multirow{7}{*}{$\begin{array}{l}\text { Eco-efficiency based on } \\
\text { different ecosystem } \\
\text { types (Eco-Ef 1) }\end{array}$} & $\begin{array}{l}E c o-E f \\
1_{\text {FaL }}\end{array}$ & Farmland eco-efficiency & $P_{A G} / E S V_{F a L}$ \\
\hline & Eco-Ef & Garden land eco-efficiency & $P_{F R} / E S V_{G a L}$ \\
\hline & $\begin{array}{l}1_{\text {GaL }} \\
\text { Eco-Ef } \\
1_{\text {FoL }}\end{array}$ & Forest land eco-efficiency & $P_{F O} / E S V_{F o L}$ \\
\hline & Eco-Ef & Grassland eco-efficiency & $P_{L /} / E S V_{G r L}$ \\
\hline & $\begin{array}{l}1_{G r L} \\
\text { Eco-Ef }\end{array}$ & Wetland eco-efficiency & $P_{F I} / E S V_{W e L}$ \\
\hline & $\begin{array}{l}1_{W e L} \\
\text { Eco-Ef } \\
1_{U r L}\end{array}$ & Urban land eco-efficiency & $P_{I N} / E S V_{U r L}$ \\
\hline & $\begin{array}{l}\text { ECO-Ef } \\
1_{\text {RoL }}\end{array}$ & Road land eco-efficiency & $P_{T R} / E S V_{R o L}$ \\
\hline \multirow{9}{*}{$\begin{array}{l}\text { Eco-efficiency based on } \\
\text { different ecosystem } \\
\text { service types (Eco-Ef 2) }\end{array}$} & $\begin{array}{l}E C O-E f \\
2_{C R}\end{array}$ & $\begin{array}{l}\text { Climate regulation eco- } \\
\text { efficiency }\end{array}$ & $P / E S V_{C R}$ \\
\hline & Eco-Ef & Atmosphere regulation & $P / E S V_{A R}$ \\
\hline & & eco-efficiency & \\
\hline & Eco-Ef & Humidity regulation eco- & $P / E S V_{H R}$ \\
\hline & $2_{H R}$ & efficiency & \\
\hline & Eco-Ef & Water and soil conservation & $P / E S V_{W C}$ \\
\hline & $\begin{array}{l}E c o-E f \\
2_{S F}\end{array}$ & $\begin{array}{l}\text { Soil formation eco- } \\
\text { efficiency }\end{array}$ & $P / E S V_{S F}$ \\
\hline & $\begin{array}{l}E c o-E f \\
2_{W R}\end{array}$ & $\begin{array}{l}\text { Waste recycling eco- } \\
\text { efficiency }\end{array}$ & $P / E S V_{W R}$ \\
\hline & $\begin{array}{l}E c o-E f \\
2_{B C}\end{array}$ & $\begin{array}{l}\text { Biological control eco- } \\
\text { efficiency }\end{array}$ & $P / E S V_{B C}$ \\
\hline Total & $\begin{array}{l}\text { Eco- } \\
E f_{\text {Total }}\end{array}$ & $\begin{array}{l}\text { General land use eco- } \\
\text { efficiency }\end{array}$ & $P / E S V$ \\
\hline
\end{tabular}

Note: 1) $P$ and $P_{i}$ represent the direct economic values of the class $i$ land ecosystem service; $E S V$ and $E S V_{i}$ represent the indirect economic values of the class i land ecosystem service.

2) $P_{A G}$ represents the economic output of agriculture, $P_{F R}$ represents the economic output of fruits and vegetables, $P_{F O}$ represents the economic output of forest wood and nuts, $P_{L I}$ represents the economic output of livestock, $P_{F I}$ represents the economic output of fish and the water supply, $P_{I N}$ represents the economic output of the industrial department, and $P_{T R}$ represents the economic output of the transportation department. of the land use. First, the eco-efficiency can be evaluated from the absolute amount of each land use type or the absolute land use ecoefficiency, which can be interpreted as the total economic output per unit of land. As a result, a larger index value corresponds to a higher direct economic benefit of the ecosystem service and a higher eco-efficiency.

Second, eco-efficiency can be evaluated from the quantity or rate of change or the relative land use eco-efficiency, which can be interpreted as the effect of the changes in the regional ecosystem service on the direct economic output. This parameter reflects the differences in eco-efficiency of the four different land ecosystem types (see Table 4). If the economic output and ecosystem services are both increasing in value, then the maintenance of the ecosystem service of the park is optimal. Larger index values correspond to lower eco-efficiency.

\section{Results}

\subsection{ESV of Gangkou industrial park}

The aforementioned algorithm for determining the ecosystem services was combined with the statistical information and data collected for Gangkou park to calculate the total value of the park's ecosystem service. In 2007, this value was approximately 118 million RMB, with approximately 47 million RMB representing the direct economic value and 71 million RMB representing the indirect economic value. In 2015, the total value of the ecosystem service was approximately 150 million RMB. Over the course of the study period, the direct economic value increased by 42 million RMB, while the indirect economic value decreased by 10 million RMB. Of the various ecosystem services, the humidity regulation service suffered serious losses in its indirect economic value of approximately 4 -fold over ten years.

In addition, the value distribution of the park's ecosystem services for forestland, farmland, wetland and garden in 2007 were $38.1 \%, 37.8 \%, 15.1 \%$ and $8.9 \%$ of the total value, respectively, whereas in 2015 , the proportions changed to $33.7 \%, 37.3 \%, 16.2 \%$ and $16.6 \%$, respectively. From 2007 to 2015, the urban ecosystem land type doubled in negative value while the soil and water conservation service doubled in positive value. Over the last 10 years, increases in

Table 4

Different eco-efficiency indicator conditions and explanations for EIPs.

\begin{tabular}{lll}
$\begin{array}{l}\text { Economic } \\
\text { output }\left(P_{i}\right)\end{array}$ & $\begin{array}{l}\text { Ecosystem } \\
\text { services } \\
\left(E S V_{i}\right)\end{array}$ & $\begin{array}{l}\text { Eco-efficiency }\left(E c o-E f_{i}\right) \\
\text { Trend Value Trend Value Value Explanation }\end{array}$ \\
\hline $1 \succ+$ & $\nearrow+$ & $\begin{array}{l}\text { The intensity of the maintenance of the } \\
\text { ecosystem service is the highest; thus, a } \\
\text { higher index value corresponds to a lower } \\
\text { ecological efficiency. } \\
\text { The strength of the maintenance of the } \\
\text { ecosystem service is low; thus, a higher } \\
\text { index value corresponds to a higher } \\
\text { ecological efficiency. } \\
\text { The strength of the maintenance of the } \\
\text { ecosystem service is high; thus, a higher } \\
\text { index value corresponds to a lower } \\
\text { ecological efficiency. } \\
\text { The strength of the maintenance of the } \\
\text { ecosystem service is the lowest; thus, a } \\
\text { higher index value corresponds to a higher } \\
\text { ecological efficiency. }\end{array}$ \\
\hline
\end{tabular}

Note: $\nearrow$ represents the economic outputs or ESVs whose trend is increasing, while $\searrow$ represents a decreasing trend; + represents a positive value for the economic outputs, ecosystem services, or eco-efficiencies, while - represents a negative value. 


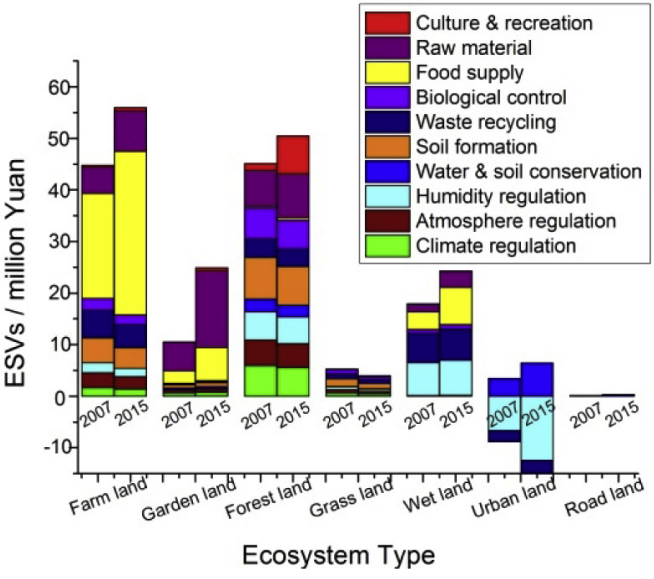

a

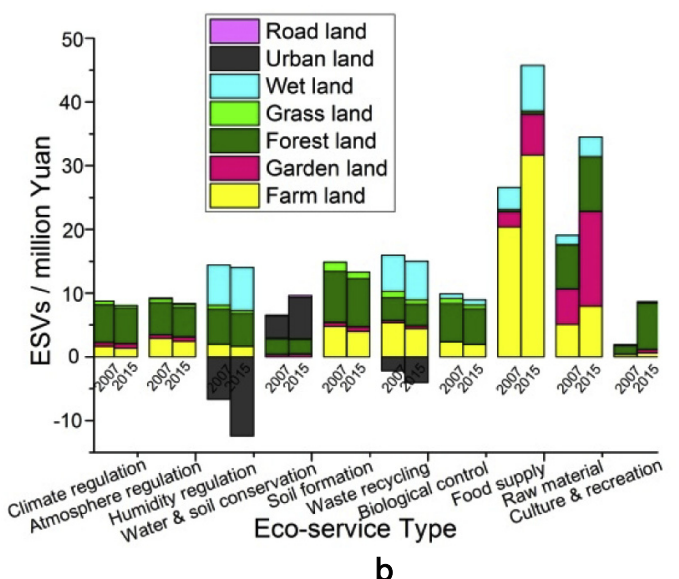

b

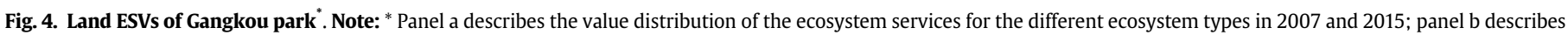
the value distribution of the ecosystem types for the different ecosystem services in 2007 and 2015.

the park's ESV were mainly reflected in its direct economic output with regards to the value of the food supply service, the raw material supply service and the cultural and recreation service, which increased by $72 \%, 81 \%$ and $351 \%$, respectively (Fig. 4).

For the indirect economic value distribution of the park's ecosystem services, the values for forestland, farmland, wetland and grassland in 2007 were $51.6 \%, 26.8 \%, 18.3 \%$ and $7.2 \%$ of the total indirect economic value, respectively, whereas in 2015 , the proportions changed to $56 \%, 25.9 \%, 22.8 \%$ and $6.2 \%$, respectively. From 2007 to 2015, the urban ecosystem doubled in negative value while the soil and water conservation service only increased in positive value by $50 \%$. Soil formation, waste recycling and biological control services accounted for $21 \%, 19.4 \%$ and $14 \%$ of the total indirect economic value in 2007, respectively, whereas all 3 services decreased to a certain extent in 2015, of which the waste circulation service decreased most substantially (by $25.1 \%$ ) compared with that of 2007.

The increases in the direct economic values of Gangkou park were mainly caused by the substantial increase in value of the raw material supplies, such as vegetables, tea, fruits and other garden plants. The decreases in the indirect economic values were mainly caused by the losses of humidity regulation services related to the expansion of urban construction land and the decline of forests and grasslands.

\subsection{Absolute land use eco-efficiency of Gangkou industrial park}

In 2007, the total direct economic value of the ecosystem services in Gangkou park was 48 million RMB and the indirect economic value was 71 million RMB. Thus, the total land use ecoefficiency in Gangkou park was 0.67 in 2007 and 1.46 in 2015.
Moreover, the average eco-efficiency of all land types in the parks was 0.73 in 2007 and increased to 1.56 in 2015. The economic outputs of the various land types and the service values of the respective ecosystems are shown in Table 5.

The eco-efficiency of farmland and garden were higher than the other land types. The eco-efficiency of the garden ecosystem reached 3.15 and 7.18 in 2007 and 2015, respectively, and these values were five times higher than the average values. The ecoefficiency of forestland and wetland were generally lower than the average level of the park. The eco-efficiency of the forestland was 0.24 and 0.48 in 2007 and 2015, respectively, and these values were three times lower than the average values. The eco-efficiency of the grassland was even lower and reached 0.03 and 0.05 in 2007 and 2015 , respectively, and these values were twenty to thirty times lower than the average value.

These results indicate that in Gangkou park, managing farmland and garden land is more efficient relative to the other land types, which is reflected in the high maintenance of ecosystem services and the generation of direct economic benefits. However, for forestland and wetlands, although these ecosystems provided for high maintenance of ecosystem services, the government could generate additional direct economic benefits by implementing ecotourism or other strategies.

\subsection{Relative land use eco-efficiency of Gangkou industrial park}

To evaluate the relative land eco-efficiency of Gangkou park, we assessed variations in the indirect economic value of the land ecosystem services or the value difference of the ESVs between 2015 and 2007, using the environmental impact and variations in the direct economic value as the economic effect. After determining

Table 5

Absolute land use eco-efficiency (Ab-Eco-Eff1) for Gangkou park*.

\begin{tabular}{|c|c|c|c|c|c|c|c|c|c|c|}
\hline & & Farmland & Garden land & Forest land & Grassland & Wet land & Urban land & Road & Total & Mean \\
\hline \multirow[t]{2}{*}{ Economic output* } & 2007 & 25.82 & 7.98 & 8.63 & 0.18 & 4.98 & 0 & 0 & 47.6 & 6.80 \\
\hline & 2015 & 40.21 & 21.85 & 16.31 & 0.17 & 10.39 & 0 & 0 & 88.93 & 12.70 \\
\hline \multirow[t]{2}{*}{ ESVs* } & 2007 & 18.96 & 2.53 & 36.49 & 5.11 & 12.93 & -5.36 & 0.12 & 70.78 & 10.11 \\
\hline & 2015 & 15.77 & 3.05 & 34.14 & 3.80 & 13.89 & -9.98 & 0.31 & 60.96 & 8.71 \\
\hline \multirow[t]{2}{*}{$A b-E c o-E f 1$} & 2007 & 1.36 & 3.15 & 0.24 & 0.03 & 0.38 & 0 & 0 & 0.67 & 0.73 \\
\hline & 2015 & 2.55 & 7.18 & 0.48 & 0.05 & 0.75 & 0 & 0 & 1.46 & 1.56 \\
\hline
\end{tabular}

unit: million RMB yuan 
Table 6

Relative land use eco-efficiency (Re-Eco-Ef1) for Gangkou park.

\begin{tabular}{|c|c|c|c|c|c|c|c|c|c|}
\hline & & Farmland & Garden land & Forest land & Grassland & Wetland & Urban land & Road & Total \\
\hline \multirow[t]{2}{*}{ Economic output* } & No. & 14.38 & 13.87 & 7.68 & -0.01 & 5.42 & - & - & 41.33 \\
\hline & St. & 3.16 & 3.14 & 2.89 & 0.35 & 2.73 & - & - & 3.62 \\
\hline \multirow[t]{2}{*}{ ESVs- $1^{* *}$} & No. & -3.2 & 0.52 & -2.36 & -1.31 & 0.96 & -4.62 & 0.19 & -9.82 \\
\hline & St. & 2.50 & 1.71 & 2.37 & 2.12 & 1.98 & 2.66 & 1.27 & 2.99 \\
\hline \multirow[t]{2}{*}{$R e-E c o-E f 1^{* * *}$} & No. & -4.5 & 26.95 & -3.26 & 0.003 & 5.67 & - & - & -4.21 \\
\hline & St. & 1.26 & 1.84 & 1.22 & 0.17 & 1.38 & - & - & 1.21 \\
\hline
\end{tabular}

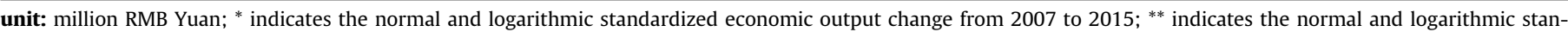
dardized ESV change from 2007 to 2015; ${ }^{* * *}$ indicates the normal and logarithmic standardized relative eco-efficiency for different land use types.

the total economic output for 2015 , we found that the direct economic value increased by 41 million RMB yuan compared with the value for 2007, whereas the indirect value for the ecosystem service decreased by 10 million RMB yuan. Because of the level of development over the last 10 years, Gangkou park generally showed a low level of ecosystem service maintenance.

Table 6 shows that the garden and wetland ecosystems presented a higher intensity of ecosystem service maintenance, which may have been derived from the direct economic output via the material supply and cultural and recreation service aspects or the indirect economic value through climate regulation, soil and water conservation and other service aspects. All ecosystems achieved a certain growth in 2015, especially the garden land ecosystem, which showed the highest level of relative eco-efficiency. Compared with the garden and wetland ecosystems, the farmland and forestland ecosystems showed a lower intensity of ecosystem service maintenance, especially the forestland ecosystem. Although the forestland ecosystem achieved a certain increase in its direct economic output rate, it also lost a large amount of its ecosystem service indirect value. The grassland ecosystem showed the lowest intensity of ecosystem service maintenance because it did not achieve increases in direct economic output or ecosystem service maintenance. Thus, over the 10year study period of Gangkou park development, a diminishing sequence of relative eco-efficiency indictors was observed for the ecosystem types for garden land, wetland, farmland, forestland and grassland (Table 6 and Fig. 5-a).

The relative eco-efficiency indictors reflected by different land use ecosystem service types indicated that the park showed the highest levels of ecosystem service maintenance for services related to soil and water conservation. Other regulating and supporting services were maintained at relatively low levels, especially the humidity regulating service, which displayed the lowest level of ecosystem service maintenance. Therefore, in this 10 -year period of development for Gangkou park, a diminishing sequence of relative eco-efficiency indictors was observed for the land ecosystem service types for soil and water conservation, climate regulation, atmosphere regulation, biological control, soil formation, waste recycling, and humidity regulation (Table 7 and Fig. 5-b).

In addition, Fig. 5 also indicates that the land types and ecosystem services reflected obvious heterogeneity in their relative eco-efficiency levels for the different types of land ecosystems and for the different types of ecosystem services. During the 10-year study period for Gangkou park, certain types of land ecosystems and the maintenance level of the ecosystem services increased, whereas others declined. Therefore, future land development and eco-management of the park should focus additional attention on the land ecosystems and their ecosystem services because certain eco-efficiency indicators showed significant downward trends.

\section{Conclusions and discussions}

\subsection{Conclusions}

The purpose of this study was to propose eco-efficiency evaluation indicators and a corresponding index system for industrial parks through land ecosystem services and their economic value. These new indicators were used to analyze Gangkou industrial park, and the main conclusions summarized below.

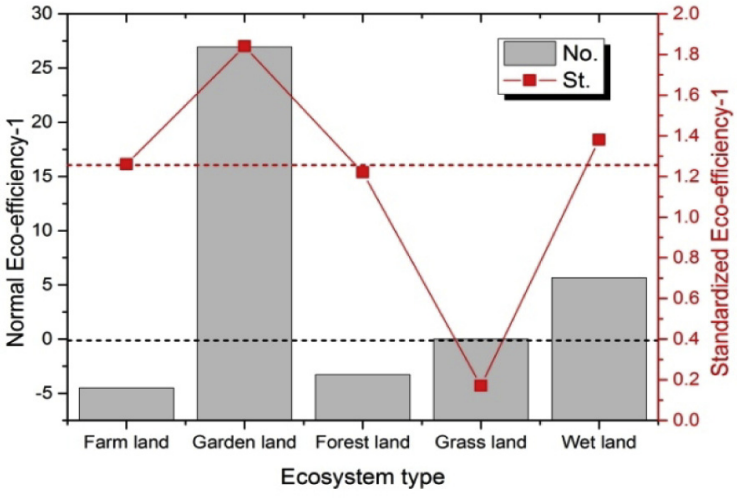

a

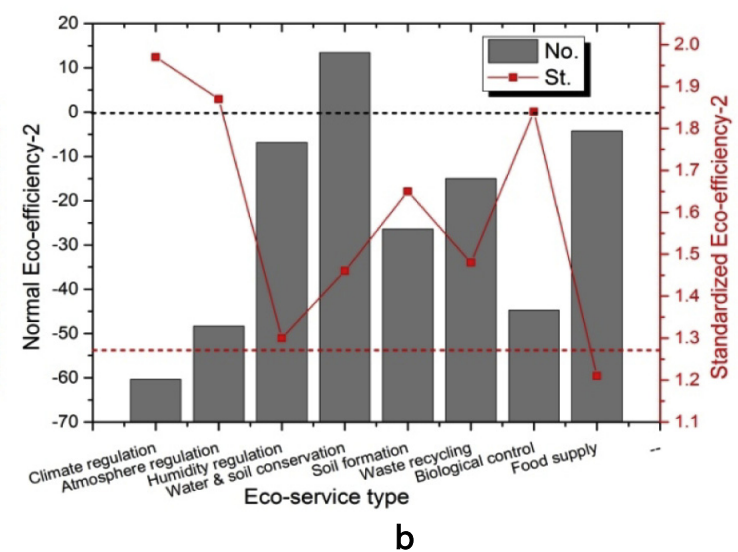

b

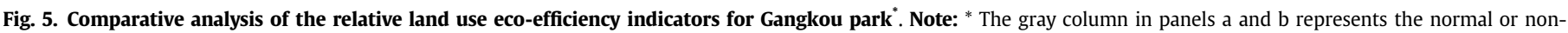

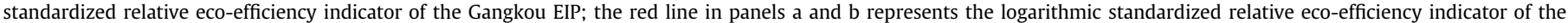

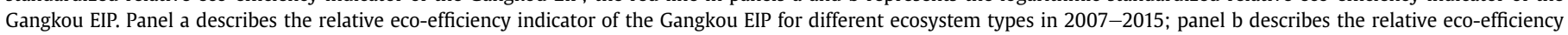
indicator of the Gangkou EIP for different ecosystem service types in 2007-2015. 
Table 7

Relative land use eco-efficiency (Re-Eco-Ef2) for Gangkou park.

\begin{tabular}{|c|c|c|c|c|c|c|c|c|c|}
\hline & & $\begin{array}{l}\text { Climate } \\
\text { regulation }\end{array}$ & $\begin{array}{l}\text { Atmosphere } \\
\text { regulation }\end{array}$ & $\begin{array}{l}\text { Humidity } \\
\text { regulation }\end{array}$ & $\begin{array}{l}\text { Water and soil } \\
\text { conservation }\end{array}$ & $\begin{array}{l}\text { Soil } \\
\text { formation }\end{array}$ & $\begin{array}{l}\text { Waste } \\
\text { recycling }\end{array}$ & $\begin{array}{l}\text { Biological } \\
\text { control }\end{array}$ & Total \\
\hline \multirow[t]{2}{*}{ ESVs-2 } & No.* & -0.69 & -0.86 & -6.10 & 3.07 & -1.57 & -2.76 & -0.92 & -9.82 \\
\hline & St.** & 1.84 & 1.93 & 2.79 & 2.49 & 2.19 & 2.44 & 1.97 & 2.99 \\
\hline \multirow{2}{*}{$\begin{array}{c}\text { Re-Eco- } \\
\text { Ef2 }\end{array}$} & No.* & -60.31 & -48.31 & -6.78 & 13.45 & -26.40 & -14.96 & -44.74 & -4.21 \\
\hline & St.** & 1.97 & 1.87 & 1.30 & 1.46 & 1.65 & 1.48 & 1.84 & 1.28 \\
\hline
\end{tabular}

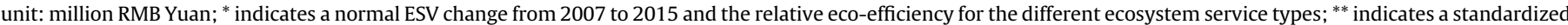
ESV change from 2007 to 2015 and the relative eco-efficiency for the different ecosystem service types.

(1) The total ESV of Gangkou park in 2015 was 150 million RMB yuan, which represented an increase of $27 \%$ compared with that of 2007. Because of urban expansion and increased industrial land use, the indirect economic value of regulating and supporting ecosystem services decreased by $14 \%$, with the humidity regulation and waste recycling services significantly decreasing. The ESV distribution of the different land ecosystems indicated that the ESVs provided by forestland, farmland and wetland ecosystems accounted for approximately $90 \%$ of the total value of the park. However, because of the impact of price fluctuations on the raw material supply service, the value of forest ecosystem services decreased by $5 \%$, and the value of the garden ecosystem services increased by $8 \%$ in 2015 compared with the values in 2007. In addition, the ESVs of the regulating and supporting services indicated that the ESVs for soil formation, waste recycling and biological control accounted for approximately $54.4 \%$ of the total indirect value of the park in 2015 , although all of these services showed declines from their values in 2007.

(2) The absolute land use eco-efficiency indicator can reflect the general capacity and intensity of the direct economic output service of an ecosystem. The general value of this indicator increased from 0.67 in 2007 to 1.46 in 2015. Because of the regional development over the last 10 years, the ecosystem service intensity based on the direct economic value and the product and raw material supply services was significantly higher than the ecosystem service intensity based on the indirect economic value and the regulating and supporting services for all of the land use types for Gangkou park. For the different land use ecosystem types, the absolute ecoefficiency indicator value for the garden ecosystem increased from 3.15 in 2007 to 7.18 in 2015, indicating that it remained at a high level over the past 10 years. In 2015, the garden ecosystem value was 5 times higher than the average value of this indicator for the entire park. The absolute ecoefficiency indicator value for the forest ecosystem increased from 0.24 in 2007 to 0.48 in 2015, indicating that it remained at a low level over the past 10 years. In 2015, the value for the forest ecosystem was 3 times lower than the average value of this indicator for the entire park.

(3) The relative land use eco-efficiency indicator can demonstrate the interrelationships and dynamic change situations between the provision of direct economic outputs and the maintenance of indirect ecological capital. This indicator revealed that over the past 10 years, the relative land use eco-efficiency or maintenance of ecosystem services for Gangkou park ranged in descending order from wetland, garden land, farmland, forestland to grassland, and the relative ecosystem service eco-efficiency or maintenance intensity ranged in descending order from soil and water conservation, climate regulation, atmosphere regulation, biological control, soil formation, waste recycling, to water regulation. We suggest that future land eco-management practices should focus additional attention on the land ecosystems and associated ecosystem services that showed significant downward trends.

\subsection{Discussions}

We have proposed a set of ecosystem service-based indicators to evaluate the ecological performance of industrial park development, and these indicators should be useful for expanding the definition of EIPs by considering the ecosystem services. The former concept of the EIP was based on research conducted by industrial symbiosis networks, and these studies were primarily focused on the industrial systems of the park. The goal of the EIP is to minimize the environmental impact and maximize the efficiency of resource utilization through the construction of industrial symbiosis network systems. Because these parks represent a regional ecosystem, we suggest that additional features of industrial parks should be considered. Currently, four types of performance parameters are considered when developing an EIP in China: economic development, resource conservation, waste reduction and environmental management. The development of multi-objective EIPs represents a considerable achievement in China (Bai et al., 2014; Tian et al., 2014). However, the ecosystem service should be added to the EIP evaluation system, especially for new parks such as Gangkou park. In such parks, additional attention should be focused on land use patterns and their ecosystem services and not just on resource use and material recycling.

In the future, EIP development should be focused on parks that present high eco-efficiency levels of land ecosystem service maintenance. In addition, EIP development should strengthen the ecomanagement of land use systems based on a comprehensive and scientific ecological assessment during planning or resource exploitation processes. For example, we could create land use account systems or land resource balance sheets based on ESV tables and ESV eco-efficiency indicators, which can also be regarded as the chief gauge of green financial investment for enterprises, and performance appraisal for government.

Certain shortcomings and uncertainties related to this study require further research. First, additional park-scale ecosystem service indicators should be developed. In this study, we adopted the traditional framework of ESV accounting at the global or national scale. However, different ecosystem services are dependent on the temporal and spatial structures and processes of specific ecosystems. The ecosystem services of the same type of land use at the industrial-park scale will not be consistent on the global and national scales, and this represents a key issue that requires additional investigation in future research.

The second uncertainty is the validity of the results in this study. The values for the land ecosystem services for Gangkou park were calculated based on various modified ESVs obtained in previous research, and they were provided according to each type of land 
ecosystem per unit area. Although the spatial heterogeneity of the quality of the ecosystem services represented by the same land type and the impact of the changes in the currency value were considered, the main parameters used to account for the ESV of Gangkou park were empirical coefficients. Thus, an important research focus for future investigations will be determining a method for scientifically designing dynamic physical and valueoriented ecosystem service accounting systems at the industrialpark scale that can be applied to resource metabolism and ecological process simulations for EIPs.

In the next phase of this work, ecosystem service accounting systems should be refined at the industrial-park scale based on the improved EIPs-MFA model (Ouyang et al., 2016; Shi et al., 2011). Subsequently, we intend to determine the balance between the supply and demand of various ecosystem services among the different types of land use or landscapes by conducting metabolic process and source-sink pathway analyses of the main nutritional elements, $\mathrm{CO}_{2}, \mathrm{O}_{2}$ and other pollutants in the industrial parks. Accordingly, we hope to identify effective approaches for the ecosystem service management of EIPs through the distribution of land use patterns and the regulation of landscape structure.

\section{Acknowledgments}

This study is supported by the National Key Technology R\&D Program (No. 2012BAC03B02), and the Key Project of Chinese National Scientific Foundation (No. 71533004).

\section{References}

Bai, L., Qiao, Q., Yao, Y., Guo, J., Xie, M., 2014. Insights on the development progress of National Demonstration eco-industrial parks in China. J. Clean. Prod. 70, 4-14.

Bakshi, B., Small, M.J., 2011. Incorporating ecosystem services into life cycle assessment. J. Ind. Ecol. 15, 477-478.

Côté, R.P., 1998. Thinking like an ecosystem. J. Ind. Ecol. 2, 9-11.

Costanza, R., d’Arge, R., De Groot, R., Faber, S., Grasso, M., Hannon, B., Limburg, K. Naeem, S., O'neill, R.V., Paruelo, J., 1997. The value of the world's ecosystem services and-natural capital. Nature 387, 253-260.

Costanza, R., de Groot, R., Sutton, P., van der Ploeg, S., Anderson, S.J., Kubiszewski, I., Farber, S., Turner, R.K., 2014. Changes in the global value of ecosystem services. Glob. Environ. Change 26, 152-158.

D’Anna, W., Cascini, G., 2016. Adding quality of life to design for Eco-Efficiency. J. Clean. Prod. 112, 3211-3221.

Daily, G.C., Söderqvist, T., Aniyar, S., Arrow, K., Dasgupta, P., Ehrlich, P.R., Folke, C., Jansson, A., Jansson, B.-O., Kautsky, N., 2000. The value of nature and the nature of value. Science 289, 395-396.

Felicio, M., Amaral, D., Esposto, K., Durany, X.G., 2016. Industrial symbiosis indicators to manage eco-industrial parks as dynamic systems. J. Clean. Prod. 118, 54-64.

Kreuter, U.P., Harris, H.G., Matlock, M.D., Lacey, R.E., 2001. Change in ecosystem service values in the San Antonio area. Tex. Ecol. Econ. 39, 333-346.
Lan, C., Tian, Y., Xu, J., Li, J., 2015. Conceptual framework and operational model of intergovernmental science-policy platform on biodiversity and ecosystem services. Biodivers. Sci. 23, 681-688.

Liu, L., Zhang, B., Bi, J., Wei, Q., He, P., 2012. The greenhouse gas mitigation of industrial parks in China: a case study of Suzhou Industrial Park. Energy Policy 46, 301-307.

Lowe, E.A., 1997. Creating by-product resource exchanges: strategies for ecoindustrial parks. J. Clean. Prod. 5, 57-65.

Lowitt, P., Côté, R., 2013. Putting the eco into eco parks. J. Ind. Ecol. 17, 343-344.

Luo, D., Zhang, W., 2014. A comparison of Markov model-based methods for predicting the ecosystem service value of land use in Wuhan, central China. Ecosyst. Serv. 7, 57-65.

Michelsen, O., Cherubini, F, Strømman, A.H., 2012. Impact assessment of biodiversity and carbon pools from land use and land use changes in life cycle assessment, exemplified with forestry operations in Norway. J. Ind. Ecol. 16, $231-242$.

Ouyang, Z., Zheng, H., Xiao, Y., Polasky, S., Liu, J., Xu, W., Wang, Q., Zhang, L., Xiao, Y., Rao, E., 2016. Improvements in ecosystem services from investments in natural capital. Science 352, 1455-1459.

Ouyang, Z.W., Rusong, Zhao, Jingzhu, 1999. Ecosystem service function and the evaluation of it's ecological economic value. Chin. J. Appl. Ecol. 10, 635-640.

Panyathanakun, V., Tantayanon, S., Tingsabhat, C., Charmondusit, K., 2013. Development of eco-industrial estates in Thailand: initiatives in the northern region community-based eco-industrial estate. J. Clean. Prod. 51, 71-79.

Park, H.-S., Behera, S.K., 2014. Methodological aspects of applying eco-efficiency indicators to industrial symbiosis networks. J. Clean. Prod. 64, 478-485.

Shi, H., Chertow, M., Song, Y., 2010. Developing country experience with ecoindustrial parks: a case study of the Tianjin Economic-Technological Development Area in China. J. Clean. Prod. 18, 191-199.

Shi, H., Moriguichi, Y., Yang, J., 2003a. Industrial ecology in China, part 1. J. Ind. Ecol. 6, 7-11.

Shi, H., Moriguichi, Y., Yang, J., 2003b. Industrial ecology in China, part II. J. Ind. Ecol. 7, 5-8.

Shi, H., Tian, J., Chen, L., 2012a. China's quest for eco-industrial parks, Part I. J. Ind. Ecol. 16, 8-10.

Shi, H., Tian, J., Chen, L., 2012b. China's quest for eco-industrial parks, Part II. J. Ind. Ecol. 16, 290.

Shi, Y., Wang, R., Huang, J., Yang, W., 2012c. An analysis of the spatial and temporal changes in Chinese terrestrial ecosystem service functions. Chin. Sci. Bull. 57, 2120-2131.

Shi, Y., Wang, R., Liu, J., Yang, J., Ju, T., 2011. The establishment of EIPs-MFA model for the evaluation of material metabolism efficiency in industrial areas. Environ. Eng. Manag. J. (EEMJ) 10.

Sokka, L., Lehtoranta, S., Nissinen, A., Melanen, M., 2011. Analyzing the environmental benefits of industrial symbiosis. J. Ind. Ecol. 15, 137-155.

TEEB, 2010. The Economics of Ecosystems and Biodiversity: Mainstreaming the Economics of Nature: a Synthesis of the Approach. Conclusions and Recommendations of TEEB.

TEEB, 2013. The Economics of Ecosystems and Biodiversity: Guidance Manual for TEEB Country Studies. Version 1.0.

Tian, J., Liu, W., Lai, B., Li, X., Chen, L., 2014. Study of the performance of ecoindustrial park development in China. J. Clean. Prod. 64, 486-494.

Yu, C., de Jong, M., Dijkema, G.P., 2014a. Process analysis of eco-industrial park development-the case of Tianjin, China. J. Clean. Prod. 64, 464-477.

Yu, C., de Jong, M., Dijkema, G.P.J., 2014b. Process analysis of eco-industrial park development - the case of Tianjin, China. J. Clean. Prod. 64, 464-477.

Yu, F., Han, F., Cui, Z., 2015. Evolution of industrial symbiosis in an eco-industrial park in China. J. Clean. Prod. 87, 339-347.

Zhang, L., Yuan, Z., Bi, J., Zhang, B., Liu, B., 2010. Eco-industrial parks: national pilot practices in China. J. Clean. Prod. 18, 504-509. 